\title{
COMPARATIVE ANALYSIS OF ONLINE NEWS CONTENT OBJECTIVITY ON COVID-19 BETWEEN DETIK.COM AND KOMPAS.COM
}

\section{USPOREDNA ANALIZA OBJEKTIVNOSTI ONLINE VIJESTI O COVIDU-19 IZMEĐU DETIK.COM I KOMPAS.COM}

\author{
Silvia Pristianita ${ }^{1}$, Rustono Farady Marta ${ }^{1}$, Mercedes Amanda², Yohanes \\ Nugroho Widiyanto ${ }^{3}$, Rino Febrianno Boer 4 \\ Universitas Bunda Mulia, Jakarta, Indonesia1; Huaqiao University, Xiamen, China²; Widya Mandala Surabaya Catholic \\ University, Surabaya, Indonesia ${ }^{3}$; LSPR Communication and Business Institute, Jakarta, Indonesia ${ }^{4}$ \\ Sveučilište Bunda Mulia, Jakarta, Indonezija ${ }^{1}$; Sveučilište Huaqiao, Xiamen, Kina²; Katoličko sveučilište Widya Mandala \\ Surabaya, Surabaya, Indonezija3; LSPR Institut za komunikaciju i poslovanje, Jakarta, Indonezija ${ }^{4}$
}

\section{Abstract}

Since March 11, 2020, COVID-19 has been declared as a global pandemic. The case of the COVID-19 has become the major topic of the media around the world because it didn't only threaten human life, it also gave negative impacts on various sectors. Many kinds of news about COVID-19, which its context started from information about the disease until it is been associated with politics and economics, have been published every day, especially in this globalization era, where information can be instantly accessed. The news about COVID-19 became overflow, at the point, various interests lead media for not being objective. While generating the news, journalists are expected to make the news objectively as it is the most important condition in journalism. Objectivity aims at presenting the real situation of some reporting events based on fact, relevance, and neutrality, which became the main factors of objective news. At the same time, it is been known that media have the power to construct social reality depending on how they created the news. This research used quantitative content analysis and was conducted in six phases from January 30th until March 15, 2020. The purpose of this research was to explain the compar-
Sažetak

Od 11. ožujka 2020. COVID-19 proglašen je globalnom pandemijom. Slučaj COVID-19 postao je glavna tema medija širom svijeta jer nije samo ugrozio ljudski život, već je proizveo i negativne utjecaje na razne sektore. Mnoge su se vijesti o COVID-19, čiji je kontekst polazio od informacija o bolesti, sve dok se nije povezala s politikom i ekonomijom, objavljivale svakodnevno, posebno u ovo doba globalizacije, gdje se informacijama može odmah pristupiti. Vijesti o COVID-19 postale su preplavljujuće, $\mathrm{u}$ trenutku kada su različiti interesi vodili medije u smjeru neobjektivnosti. Dok generiraju vijesti, od novinara se očekuje da ih stvaraju objektivno, jer je to najvažniji uvjet u novinarstvu. Objektivnost ima za cilj prikazati stvarno stanje nekih izvještajnih događaja na temelju činjenica, relevantnosti i neutralnosti, što je postalo glavnim čimbenicima objektivnih vijesti. Istodobno, poznato je da mediji imaju moć konstruiranja društvene stvarnosti ovisno o tome kako su stvorili vijest. Ovo istraživanje koristilo je kvantitativnu analizu sadržaja i provodilo se u šest faza od 30. siječnja do 15. ožujka 2020. Svrha ovog istraživanja bila je objasniti usporednu objektivnost dviju glavnih internetskih portala s vijestima u Indoneziji (detik.com i kompas.com.) o izvještavanju o COVID-19. 
ative objectivity of two main online news in Indonesia (namely, detik.com and kompas.com.) on reporting COVID-19.

\section{INTRODUCTION}

Corona Virus has actually been the subject of discussion and research in the medical field for a long time. Corona Virus infection to humans previously occurred in 2003 known as the Severe Acute Respiratory Syndrome CoV (SARS$\mathrm{CoV}$ ) and Middle-East Respiratory Syndrome $\mathrm{CoV}$ (Mers-CoV) outbreak. The plague infected more than 8000 humans and caused 774 deaths $/ \mathbf{1} /$.

Declared as a global pandemic on March 11, 2020, COVID-19 in Indonesia certainly has negative impact on various aspects, and to make it worse, it is estimated that it will take a long time to overcome $/ \mathbf{2} /$.

At the beginning of this pandemic, ethnic Chinese or Chinese citizens had to experience not only flight restrictions and isolation but also suspicion that they might have carried the virus and potentially transmitted it to other local people. This health issue has the potential to be an inter-ethnic conflict which has been one of the greatest challenges in multi ethnical society /4/. The fact that COVID-19 can indeed be transmitted from humans to other humans through contact with infected people in turn increased the alertness $/ 4 /$.

With its dramatic spread, COVID-19 has paralyzed many crucial sectors globally, such as the economy, tourism, politics, and even the education sector $/ 5 /$, /6/. President Joko Widodo on March 2, 2020 declared officially that COVID-19 had spread in Indonesia dan suggested that working, teaching-learning and even religious activities be conducted from home /7/. This had a huge impact on the economic sector, where most offices and factory had to be closed and also everyone had to reduce activities outside the home /8/. Due to this, COVID-19 had caught the attention of the world community and certainly the media. The overflown news about COVID-19 in online media and also various other news media can certainly create stigma for those infected by this disease. News coverage in a media is closely related to various interests which can make the media less objective /9/.

Mass media has the power to shape social reality depended on the way it is covered by the media crew. Based on the views of Berger and Luckman, it can be understood that the objectivity displayed by the mass media is the subjectivity formed by the person who makes the media text. Mass media are able to shape social reality itself due to the characteristics of the media which can massively construct the reality of events in the form of media news texts $/ \mathbf{1 0} /$.

Fairclough views language not just a means of interaction, but a powerful tool for understanding meaning and representing goals of the communicator's actions $/ \mathbf{1 1} /$.

The fact that the extreme spread of COVID-19 has been reported and analyzed critically by credible media in Indonesia, and even in the whole world, attracted the researchers to examine whether the news content regarding the issue of COVID-19 in credible online media in Indonesia shows the level of objectivity.

Objectivity is a method in journalistic practice by presenting an honest and accurate picture in the news. The presentation of news should be based on truth, impartial and also balanced, in which facts, relevance, and neutrality become the main factors of a news item. Furthermore, McQuail defines objectivity as a condition when journalists leaves their subjectivity and personal opinion about an event that will be used as news $/ \mathbf{1 2} /$.

The research focuses on the objectivity of the content of the news about COVID-19 presented by kompas.com and detik.com from January 30 , 2020 to March 15, 2020. Researchers were interested in researching this issue despite John C. Merril's precaution in Eriyanto (2000) that journalistic objectivity is impossible to materialize because all journalistic activities are basically subjective $/ \mathbf{1 2} /$. 


\section{Theoretical Framework}

\section{Mass Media}

Blake dan Haroldsen emphasize that the mass media is known by modern society as an institution whose job is to disseminate messages. These messages of course include formal messages as well as informal messages important for public /13/.

However, Eriyanto critically states that the media pay different attention to each issue happening. Differences in media attention to an issue will affect the recognition of the event before society. The public tends to know an issue through the mass media, where they accept the priority list presented by the mass media on various existing issues /14/.

In addition, McQuail argues that mass media is a means to develop culture, which comprises of symbols, art, fashion, rules, behavior patterns, and various provisions of society. Mass media has an important role in the development or change of behavior of society /15/.

\section{Online Media}

Online media has an important role in contributing to the presentation of news in today's modern society. Along with its technology advancement, online media become more attractive since it can include text, image, audio and video news in presenting news /16/.

One of online media characteristics that make it more competitive when juxtaposed with conventional media is its speed of information. The use of internet networks in the field of journalism certainly has several advantages over conventional media. It is in line with JR Dominick's (2009) argument saying that online media has no limitations in presenting news and is also more attractive due to the multimedia presentation used /17/.

Various existing technological developments certainly support the rapid growth of online media. In fact, according to the Indonesian Internet Service Providers Association, internet users have always experienced an increase and will continue to increase every year /18/.
Online media has various characteristics, such as immediacy, multiple pagination, multimedia, archiving and also relationship with readers $/ \mathbf{1 9} /$.

The five characteristics of online media that have been previously mentioned are also described in detail by Mike Ward /20/.

However, people find that the news contained in online media lack of several elements, such as completeness, accuracy, justice and also the neutrality of the news because news tends to catch up with broadcasts. The elements of online media speed should also need to be balanced with the objectivity of journalists in presenting news, so that it is free from prejudice and opinion from journalists /21/.

\section{Social Responsibility Theory}

The theory of social responsibility press discusses the obligation of the media to serve the interests of society rather than of the owners or of individual journalists /22/. The theory is based the ethical aspects of individuals as a doer of every action $/ \mathbf{2 3 / \text { . }}$

According to Sumadiria, social media responsibility theory believes that in exercising its freedom, media, due to its very important position in reporting an issue, must carry out discussion in the community through a free and responsible market.of ideas $/ 24 /$.

Media is the only industry protected by the Charter of Human Rights and must fulfil its social responsibilities. This has occurred due to the evolution in the ideas among media practitioners, media laws and also the freedom of press $/ 25 /$.

McQuail insists that social responsibility press has several characteristics; among them are that the media accept and also fulfill obligations in society; it has obligation and professionalism in presenting information with truth, accuracy, objectivity and balance; it must be able to independently organize themselves and position them within the legal framework and related institutions; the media should avoid things that can be or are related to crime, public disorder and insult to minorities, both ethnic and religious groups; the media must be pluralist in nature and reflect diversity. In addition, by giving them the right to express new 
points of view and also the right to answer; society has the right to demand high standards of achievement and professionalism to prioritize common interests $/ \mathbf{2 6} /$.

In order to maintain this social responsibility, journalists have journalistic rules or principles known as the Journalistic Code of Ethics, which is spelled out in Law No. 40 of 1999 about The Press.

The code of ethics is intended to guide the journalists carrying out journalistic activities to present news that is accurate, balanced, in accordance with the facts and also not detrimental to others $/ \mathbf{2 7} /$.

The fact that the ethic code is regulated does not guarantee that it is always observed by journalists, including those of online media. It should be realized by journalists that professionalism in reporting should be measured from various aspects and that the objectivity of the news, which is independent from various individual or corporate interests, should be maintained /28/.

Dennis McQuail, furthermore, argues that objectivity is the main principle of journalism. The problem is that most online media do not have clear standards in editorial review to analyze or verify the information in news content. Since objectivity is one of the important principles in journalism, the unclear standards among online

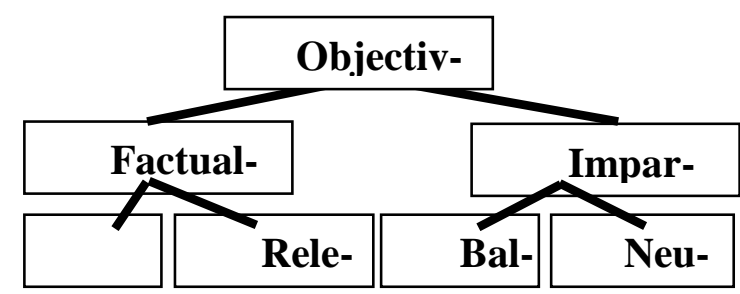

media actually makes a regression to the tradition of objectivity, in which news tends to be more interpretive and is not in accordance with professional ethics like objectivity and verification as in traditional journalism /25/.

\section{Westerstahl Objectivity}

Sambrook underlies that "Objectivity" is closely related to the performance and ethics of media journalists. For professional journalists, objectivity and impartiality are norms used to avoid bias and subjectivity and increase confidence in the journalism profession itself $/ 29 /$.

The objectivity of news according to Manan is one of the ethics in the journalistic activities along with the values, norms and code of ethics adopted by journalists $/ \mathbf{3 0} /$.

To find out the level of neutrality and balance of news, J. Westerstahl, a researcher from Sweden, carried the formulation of the concept of objectivity. Westerstahl explained that objectivity is specified into two, namely cognitive aspects (factuality) related to the quality of news delivery and evaluative aspects (impartiality) related to systematic aspects of how an event is reported. Factuality is then divided into truth and relevance, meanwhile impartiality consists of balance and neutrality /31/.

Figure 1- The scheme of objectivity concept Source : Westerståhl /32/

The factuality is referred to factual and verifiable. Meanwhile, impartiality is related to impartiality in delivering news and also neutrality in writing news $/ 29 /$.

Table-1 Dimensions dan indicators

\begin{tabular}{ll}
\hline Dimensions & Indicators \\
\hline Factuality & Fact \\
& Sociological \\
\hline
\end{tabular}

The following table describes the framework using Westerstahl's concept of objectivity which has been modified and adapted for this study. 


\begin{tabular}{ll}
\hline \hline & Psychological \\
Combination & Accuracy \\
& Time \\
& Attribution \\
& News values \\
Relevance & Cover Both Sides \\
Impartiality & Non evaluative \\
Ballance & Mixing facts dan opinions \\
& Non Sensational \\
& Matching between title and \\
content & Dramatization \\
\hline
\end{tabular}

Source: Processed by Researcher's

Truth consists of facts and accuracy. According to Sinansari Ecip, facts in journalism consist of sociological facts, events that actually happen, and psychological facts, statements from one or several people about an event happening and intended to be reported /33/. Accuracy is related to the completeness of reporting, such as the inclusion of time and location of an event to be reported $/ 34 /$.

\section{METHODS}

\section{Research Methodology}

The present research is quantitative in nature, in which the researcher is required to address the research objectively. Researchers must have eliminated existing biases, tendencies and alignments /35/. Furthermore, it can be identified as a descriptive quantitative research in which it intended to provide an overview, describe, or summarize various conditions, situations and phenomena from a variety of research variables which can be revealed through photographs, observation, interviewing or documentaries $/ 36 /$.

In drawing the samples, researchers chose news channels or headlines from both Kompas.com and Detik.com. Researchers divided the time span over 6 periods, namely 30 January - 6 Feb- ruary 2020 or 7 days when COVID-19 was declared as a global emergency, 7 - 14 February 2020 as the second week, 15-22 February 2020 as the third week, 23 February 2020 - 1 March 2020 as the fourth week, 2 March - 8 March 2020 COVID-19 has infected Indonesia and 9 March - 15 March 2020 when the WHO declared COVID-19 a global pandemic.

In taking the sample, the researchers used a systematic random sample, in which the researcher initially determined a sample of 30 news items from each media which could be detailed as 10 from each time period, so that there were 60 news items to study.

Researchers drew news samples from the two online news websites, namely kompas.com and detik.co. To justify the strength of these two online news agencies, Alexa.com, a websiteranking analysis site, was referred to know the ranking of the two sites, in which Detik.com and Kompas.com are in the 5th and 6th positions of the websites with the most traffic in Indonesia. However, the amount of traffic was not the only consideration in choosing the two online media. Researchers also looked at the presentation and also the level of popularity of news about COVID-19 being reported in their respective media. The comparison of four online media websites in terms of popularity and traffic can be seen in the following tables. 
Table 2- Online Media Comparation of Traffic and Popularity

\begin{tabular}{lrc}
\hline Media (.com) & \% Traffic & Popularity \\
\hline Okezone & $0,46 \%$ & 18 \\
Tribunnews & $0,04 \%$ & 50 \\
Detik & $0,35 \%$ & 50 \\
Kompas & $0,74 \%$ & 50 \\
\hline
\end{tabular}

Source: Alexa.com

There were four news websites that were the top sites, when the researchers sorted the websites. The two data at that time were taken from search engines, namely google.com and youtube.com.

When doing the coding process, the researcher did it with other colleagues; a reporter from the Grid Network and also a bachelor of Communication Science. These other coders were recruited because this research had to be objec- tive, not subjective, so that in drawing conclusions, it was not based on the researcher's thoughts alone.

\section{RESULT AND DISCUSSION}

The results of this research are described comprehensively in the following graphs. The research results were obtained after analyzing the news with other credible coders. The description of the result in kompas.com is initially explored.

\section{Kompas.com}

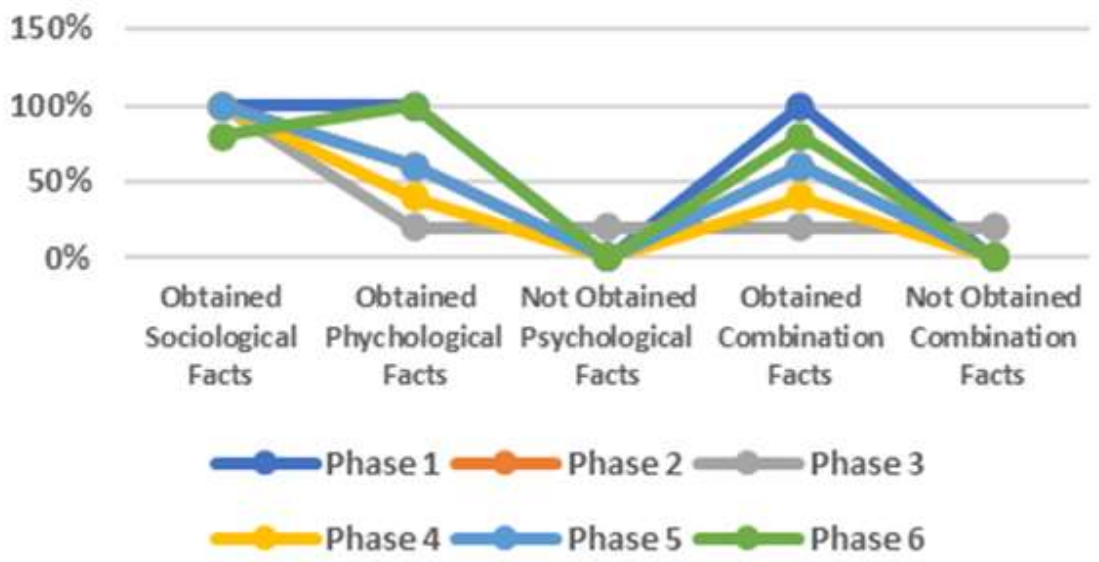

Figure 2: Chart phases at Kompas.com

Source: Researcher's Mapping

The first graph describes the presence of the use of sociological facts, psychological facts, the absence of sociological facts, the use of combination facts and also the absence of the use of combined facts.

It was found that in the first to fifth phases, sociological facts were still used as a whole or as much as $100 \%$, and in the sixth phase it was found that only $80 \%$ of the total number were concluded to have sociological facts.
Unlike the use of social facts, psychological facts were found to be high in the first and sixth phases, i.e. $100 \%$, while in the second and fifth phases it was $60 \%$, the fourth phase was $40 \%$ and $20 \%$ in the third phase.

The same percentage can be seen in the use of combined facts in kompas.com, in which it was slightly different in the sixth phase where there were only $80 \%$ combined facts. 
It was also found that $20 \%$ of the reports did not use psychological facts and combined facts in the third phase.

\section{Kompas.com}

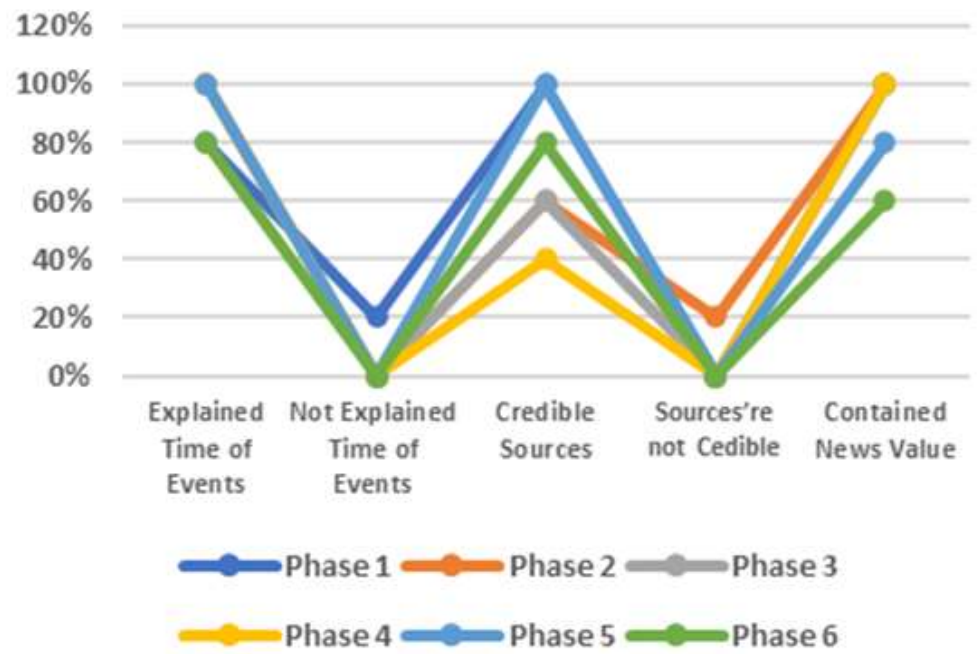

Figure 3: Chart phase at Kompas.com

Source: Researcher's Mapping

The second graph consists of the inclusion of event time, the exclusion of event time, reliable sources, untrusted sources and the presence of news value.

In the first and last phases, it was found that only $80 \%$ of the reports included the time of the event, while the second to fifth phases as a whole or $100 \%$ included the time of the incident.

It can be concluded that that in the first phase there was no explanation regarding the timing of the events reported by journalists.
It was also found that $20 \%$ of the news did not have a reliable source in the second phase, while in the first and fifth phases $100 \%$ of the news had a reliable source, and $60 \%$ in the third phase and $80 \%$ in the sixth phase.

In the first to fourth phases, it was found that $100 \%$ of the items have news value, while in the fifth phase it was only $80 \%$ and in the sixth phase, $60 \%$. 


\section{Kompas.com}

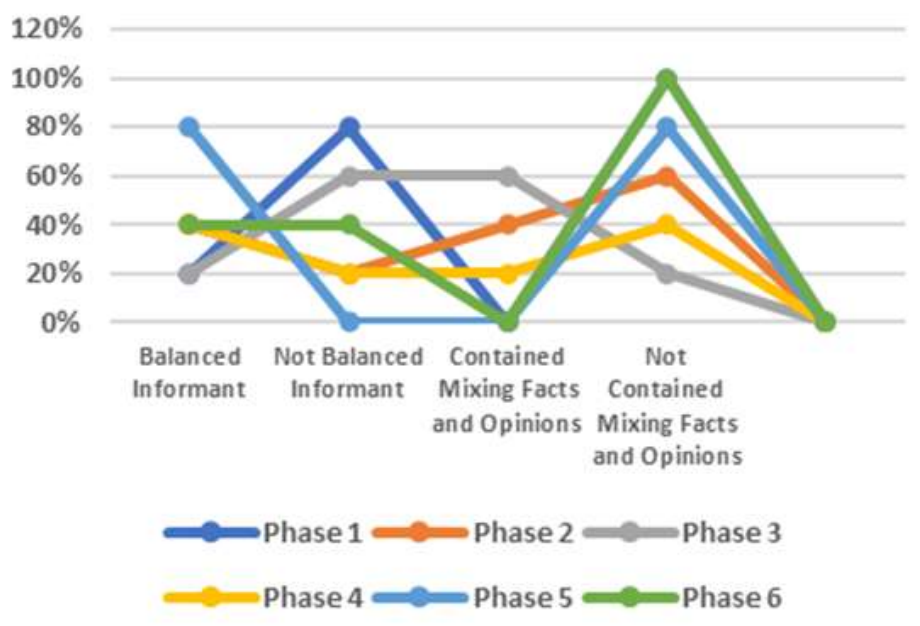

Figure 4: Chart phases at Kompas.com

Source: Researcher's Mapping

The third graph consists of the balance and imbalance of the sources, whether or not there is a mixture of facts and opinions, as well as the relationship between the title and the content of the news.

In the first phase, the balance of the informants was only $20 \%$, this also happened in the third phase; the second, fourth and sixth phases, it increased to be $40 \%$, the fifth phase was $80 \%$. In addition, the imbalance of sources was found to be the greatest in the first phase, where $80 \%$ of the news items showed that. The second and fourth phases were the lowest at $20 \%$, while the third and sixth phase respectively showed $60 \%$ of imbalance. In the fifth phase, it was found that there was no source imbalance from the results of the coding carried out.

There was a mixture of opinions in the second, third and fourth phases, respectfully $40 \%, 60 \%$ and $20 \%$. On the other hand, there was no mixing of opinions at $100 \%$ in the first phase, $60 \%$ in the second phase, $20 \%$ in the third phase, $40 \%$ in the fourth phase. $80 \%$ in the fifth phase and $100 \%$ in the sixth phase.

At kompas.com, the title and content had a complete match in the first, fifth and sixth phases, meanwhile in the second and fourth phases, there was $80 \%$ and only $60 \%$ of the complete matching in the third phase. 


\section{Kompas.com}

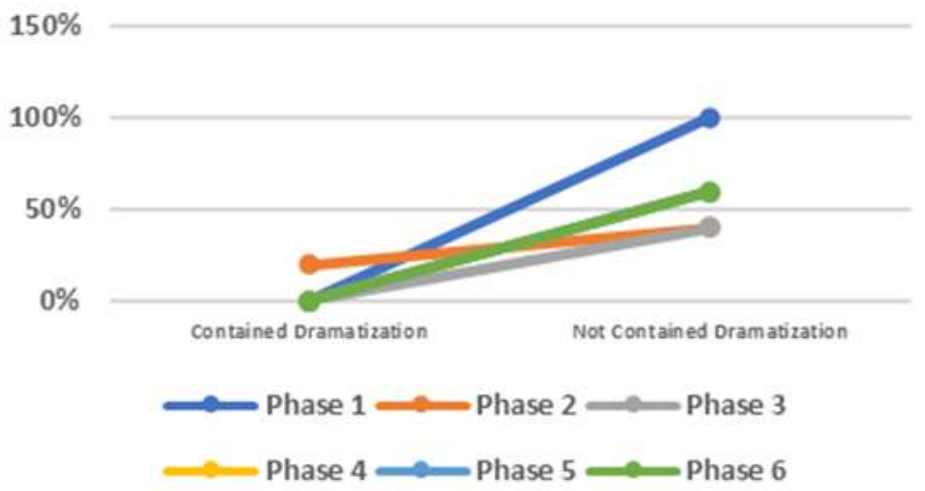

Figure 5: Chart phases at Kompas.com

Source: Researcher's Mapping

In the fourth graph, consisting of the presence or absence of dramatization, it was found that the dramatization was found in $20 \%$ of the news items in the second phase, and $100 \%$ of the news did not contain dramatization in the first phase, $60 \%$ in the fourth, fifth and sixth phases, $40 \%$ in the second and third phases. The same thing was conducted by researchers in analyzing the news contained in the detik.com media and the results will be described in detail with following graphics and explanations.

\section{Detik.com}

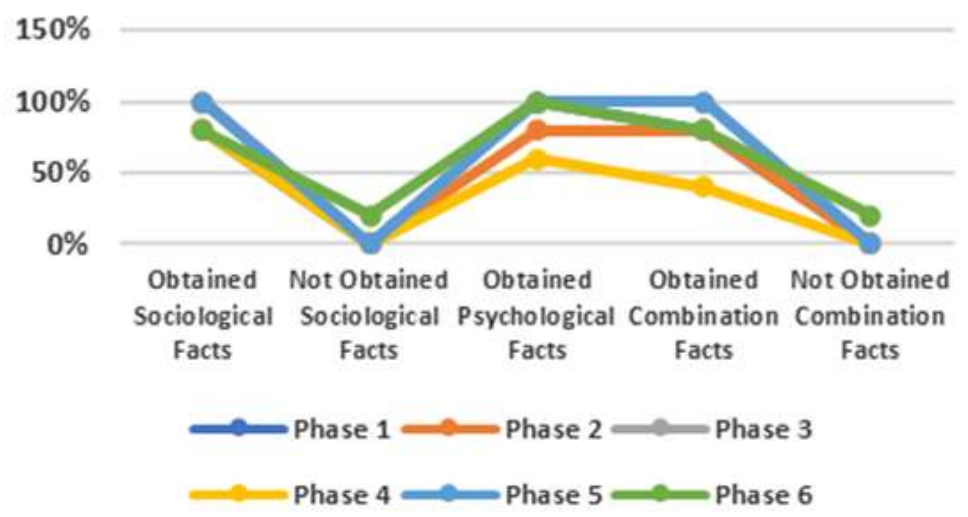

Figure 6: Chart phases at Detik.com

Source: Researcher's Mapping

On detik.com, $100 \%$ of the news contained sociological facts in the second, third and fifth phases, while in the first, fourth and sixth phases there was only $80 \%$ of the news contain- ing sociological facts. Based on the coding results of the three coders, it was found that $20 \%$ of the news was in the sixth phase.

It was found that $100 \%$ news items in detik.com used psychological facts in the first, third, fifth and sixth phases, $80 \%$ in the second phase and $60 \%$ in the fourth phase. Meanwhile, $80 \%$ of them used combination facts in the first, second 
and sixth phases. The highest percentage of $100 \%$ happened in the third and fifth phases, the fourth phase recorded the lowest at $40 \%$.
The combination facts were not found in the news on detik.com in the sixth phase.

\section{Detik.com}

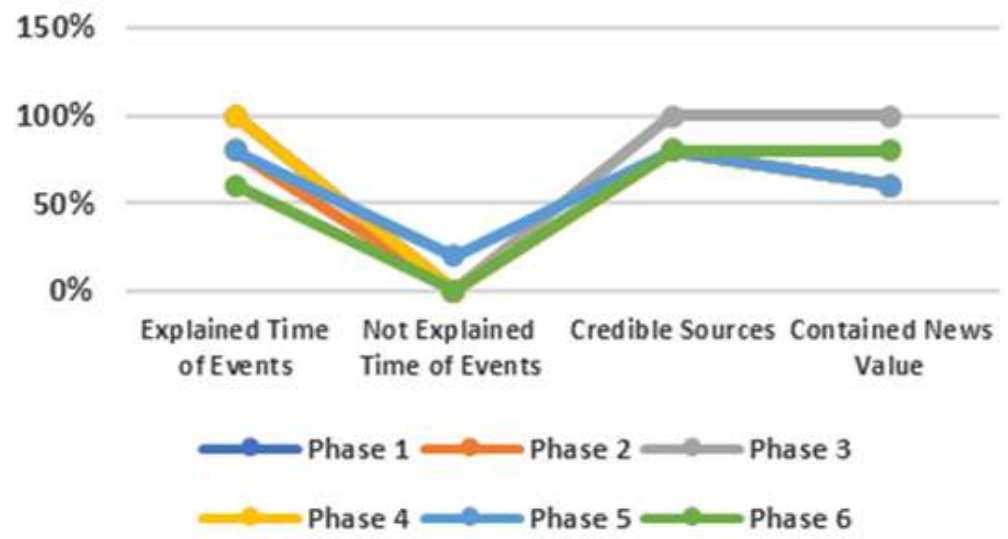

Figure 7: Chart phases at Detik.com

Source: Researcher's Mapping

The news on detik.com was found not to include the time in the fifth phase, while in the first, third and fourth phase the news was comprehensive or $100 \%$ included the time of the event, as much as $80 \%$ in the second and fifth phases, and $60 \%$ in the sixth phase.

At detik.com, it was only in the third phase which had $100 \%$ reliable sources, while the other phases, including the first, second, fourth, fifth and sixth phases, there were only $80 \%$. The same thing can also be seen in the presence of news values in the third phase as a whole, but in the first, second, fourth and fifth phases, there was only $60 \%$ and $80 \%$ in the sixth phase.

\section{Detik.com}

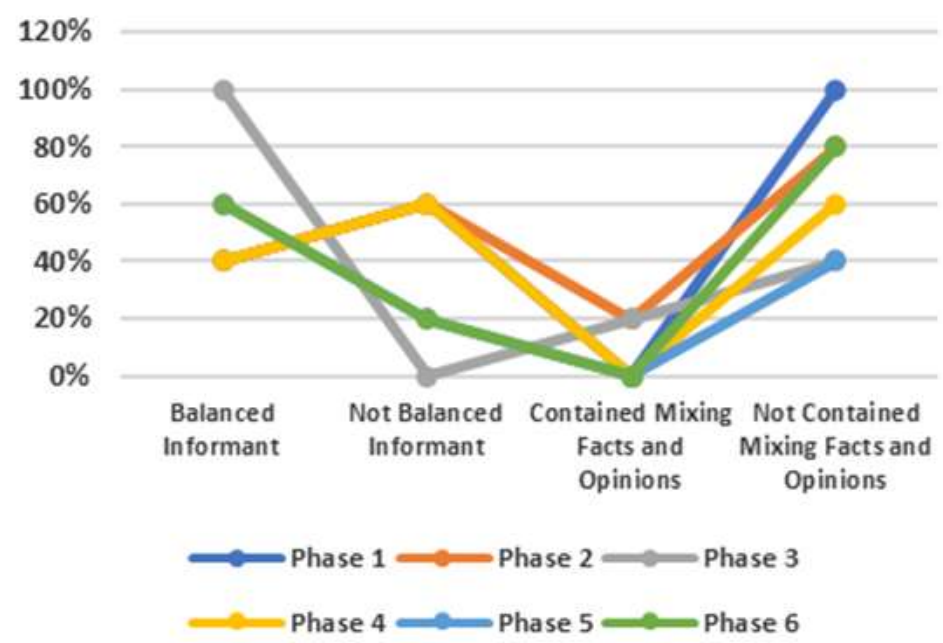

Figure 8: Chart phases at Detik.com

Source: Researcher's Mapping 
In the first, second and fourth phases, only $40 \%$ had a balance of resource persons, $100 \%$ in the third phase and $60 \%$ in the fifth and sixth phases. It can be seen on detik.com that there were quite a lot of news stories that do not have a balance of sources, namely $60 \%$ in the first, second and third phases, and $20 \%$ in the fifth and sixth phases.

On detik.com there was also news that mixed facts and opinions by $20 \%$ in the second and third phases. However, it was also found that there was no mixing of facts and opinions in the first phase, $80 \%$ in the second and sixth phases,
$40 \%$ in the third and fifth phases, and $60 \%$ in the fourth phase.

Based on the coding results of various coder's statements, there was no news that had no continuity between content and title.

On detik.com, it was found that $60 \%$ of news stories have a balance of content and titles in the first phase, $80 \%$ in the second phase and a perfect $100 \%$ of news in the third, fourth, fifth and sixth phases. This description can be seen in the fourth graph.

\section{Detik.com}

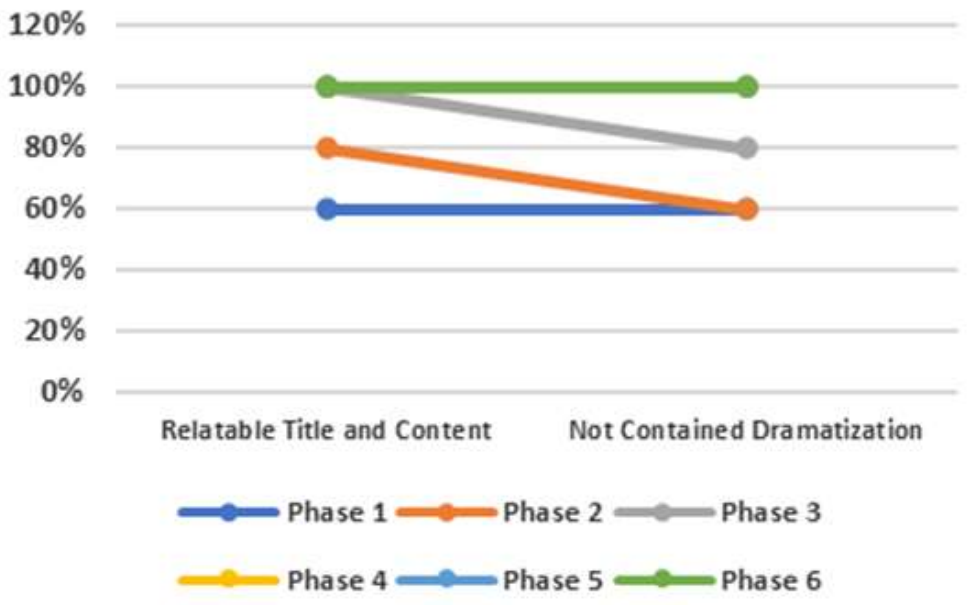

Figure 9: Chart phases at Detik.com

Source: Researcher's Mapping

On detik.com, relatively there was no news that contained dramatization, in which $60 \%$ in the first and second phases detik.com does not contain dramatization, $80 \%$ in the third phase and $100 \%$ in the fourth, fifth and sixth phases.

\section{CONCLUSION}

The research has showed the results of analysis on 60 news items; 30 news from kompas.com as well as 30 news from detik.com. The items were divided into six periods from 30 January 2020 to 15 March 2020.

The researchers conclude that the two online media, both kompas.com and detik.com, are not objective in reporting COVID-19 based on Westerstahl's standards of objectivity.

The non-objectivity of the two online media can be seen from the low balance of sources both from kompas.com and detik.com at certain phases. Just like in the first phase of kompas.com, there were only $20 \%$ news with balanced sources. In the next phase, only $40 \%$ of news, $20 \%$ of news in the third phase, $40 \%$ of news in the fourth phase and the highest $(80 \%$ of news) is in the fifth phase, but then drops again to $40 \%$ in the sixth phase.

At detik.com the highest balance is the third phase, in which five news stories have a balance of sources. In the first phase there are only two news, the second phase consists of two news, the fourth phase two news, the fifth and sixth phase three news.

This non-objectivity can also be seen from a variety of other factors such as news values. On detik.com, it is only $60 \%$ of the news in the first, second, fourth, fifth phases containing values. 
In the third phase, $100 \%$ of the news has news value, while in the sixth phase $80 \%$.

The news in kompas.com and detik.com also contains a mixture of facts and opinions, in which in the second, third and fourth phases, the opinion rather than fact reach $40 \%, 60 \%$ and $20 \%$ respectfully.

On detik.com, the news still contains a mixture of facts and opinions, in which $20 \%$ news in the second and third phases contain opinion only. Therefore, the researchers conclude that the two online media are not objective in reporting COVID-19

Notes

/1/ M. J. Nangoy, T. A. Ransaleleh, and I. Wahyuni, "Bat Coronavirus of Pteropus alecto from Gorontalo Province, Indonesia," Int. J. Trop. Vet. Biomed. Res., vol. 3, no. November, pp. 36-42, 2018.

/2/ R. Djalante et al., "Review and analysis of current responses to COVID-19 in Indonesia: Period of January to March 2020," Prog. Disaster Sci., vol. 6, p. 100091, 2020, doi: 10.1016/j.pdisas.2020.100091.

/3/ R. F. Marta and J. Fernando, "Dialectics of Forgiveness between Ethnic Communities for West Kalimantan Harmony," J. Messenger, vol. 12 , no. 1 , p. 1, 2020, doi:10.26623/themessenger.v12i1.1408.

/4/ Q. Li et al., "Early Transmission Dynamics in Wuhan, China, of Novel Coronavirus-Infected Pneumonia," N. Engl. J. Med., pp. 1-9, 2020, doi: 10.1056/nejmoa2001316.

/5/ M. Chinmi, R. F. Marta, C. G. Haryono, J. Fernando, and J. K. Goswami, “Exploring online news as comparative study between Vendatu at Indiaand Ruangguru from Indonesia in COVID19 pandemic," J. Content, Community Commun., vol. 10, no. 6, pp. 167-176, Jun. 2020, doi: 10.31620/JCCC.06.20/13.

/6/ M. Chinmi and R. F. Marta, "RuangGuru as an Ideation of Interaction and Education Revolution during COVID-19 Pandemic in Indonesia 2 . COVID-19 In Indonesia," LUMEN Journals, vol. 12, no. 2, pp. 118-129, 2020, doi: https://doi.org/10.18662/rrem/12.2Sup1/297.

/7/ H. Tannady, Resdiansyah, J. F. Andry, and R. F. Marta, "Exploring the role of ICT readiness and information sharing on supply chain performance in coronavirus disruptions," Technol. Reports Kansai Univ., vol. 62, no. 5, pp. 2581-2588, 2020.

/8/ R. Farady Marta et al., "Author compliance in following open journal system of communication science in Indonesia," J. Phys. Conf. Ser., vol. 1175, no. 1, pp. 0-10, 2019, doi: 10.1088/17426596/1175/1/012222.

19/ A. Yuliarti, M. T. Kasnawi, and H. Cangara, "Isis Dan Stigma Islamofobia Framing Tentang Konstruksi Pemberitaan Isis Dalam Media Online," KAREBA J. Ilmu Komun., vol. 6, no. 2, p. 285, 2017, doi: 10.31947/kjik.v6i2.5329.

/10/ K. Wazis, Konstruksi Realitas Media Massa: Studi Fenomenologi Awak Redaksi. Yogyakarta: Suluh Media, 2018.

/11/ Liem S., Marta D. R. F., and P. D. phil. Panggabean H. (2019), "Sanitation Behavior and Risk of Stunting: Understanding the Discourse of a Public Service Announcement," J. Messenger, vol. 11, no. 2, p. 168, doi: 10.26623/themessenger.v11i2.1317.

/12/ Effendy R. (2016), “Mengukur Objektivitas Liputan Media Dengan Rumus Coefficient Of Imbalance (Studi Kasus Hasil Penelitian Metode Analisis Isi Kuantitatif Pemberitaan Kampanye Pemilu 1999 di Harian Jawa Pos dan Republika Terhadap Partai Golkar dan PDI-P)," J. Nomosleca, vol. 2, no. 1, doi: 10.26905/nomosleca.v2i1.340.

/13/ Susanto E. H. (2017), "Media Massa, Pemerintah dan Pemilik Modal," J. ASPIKOM, vol. 1 , no. 6 , p. 477 , doi: 10.24329/aspikom.v1i6.53.

/14/ Suwarno and Suryawati I. (2019), “Akurasi Berita Bencana di Media Online ( Analisis Isi Berita Bencana Lombok dan Bencana Donggala-Palu ) ( Analysis of News Content Between Lombok Disaster and Donggala-Palu Disaster )," J. Perspekt. Komun., vol. 3, no. 2, pp. 59-70.

/15/ Kurniawansyah E. and Sumitro (2020), “Peran Media Massa Dalam Pengembangan Budaya Akademik Mahasiswa Kabupaten Sumbawa," J. Mandalanursa, vol. 4, no. 3, pp. 254-262.

/16/ Adhiarso D. S., Utari P., and Slamet Y. (2017), "Pemberitaan Hoax di Media Online Ditinjau dari Konstruksi Berita dan Respons Netizen," J. Ilmu Komun., vol. 15, no. 3, pp. 215-225.

/17/ Puspita R. (2019), “Mediamorfosis Surat Kabar Ke Surat Kabar Online," J. Komunikasi, Masy. dan Keamanan, vol. 1, no. 1, pp. 11-28.

/18/ Nurrahmi F., Sari J., Marta R. F., Setiawan Y. B., and Rahim R. (2018), “Aceh young users purchase intention by online store exposure on Facebook," Int. J. Data Netw. Sci., vol. 2, pp. 4148, doi: 10.5267/j.ijdns.2018.7.004.

/19/ Hoerunnisa L., Muchtar K., and Suryana C. (2020), "Kredibilitas media online dalam 
pandangan mahasiswa 1)," Communiverse J. Ilmu Komun., vol. 5, no. 2, pp. 122-136, doi: https://doi.org/10.36341/cmv.v5i2.1151.

/20/ Suseno A. and Rusdi F. (2019), "Strategi Penyajian Berita Brilio.net (Studi Kasus: Media Online Menjangkau Generasi Milenial)," Koneksi, vol. 3, no. 1, p. 182, doi: 10.24912/kn.v3i1.6202.

/21/ Suratno G. andSuryawati I. (2019), “Objektivitas Berita Bencana Gempa Lombok di Media Online," Communication, vol. 10, no. 1, pp. 1-9, doi: .1037//0033-2909.I26.1.78.

/22/ Rahmi (2019), "Kebebasan Pers dan Demokrasi di Indonesia," J. Komun. dan Kebud., vol. 6, pp. 78-85.

/23/ Sudarsana I. K., Purandina I. P. Y., Joyo P. R., Bagus I., Saitya S., and Putu N. (2020), "Implementation Of Value And Moral Philosophy In Multicultural Education In School," vol. 12, no. 06, pp. 2948-2956, doi: 10.5373/JARDCS/V12I6/S20201258.

/24/ Anggara R. F. (2015), “Analisis Isi Tajuk Rencana tentang Korupsi di Surat Kabar Harian Kedaulatan Rakyat," J. Ilmu Komun., vol. 13, no. 1, pp. 78-95.

/25/ Abkoriyah H. and Dewi T. T. (2017), “Objektivitas berita di Harian Kompas dan Kompas.com (Analisis isi pemberitaan kasus pembunuhan Engeline)," Cover. J. Strateg. Commun., vol. 7, no. 2, pp. 40-53.

/26/ Fretes M. D. E. and Kaligis R. A. W. (2018), "Implementasi Teori Pers Tanggung Jawab Sosial Dalam Pemberitaan TVRI Pusat," Cover. J. Strateg. Commun., vol. 9, no. 1, pp. 26-34, doi: https://doi.org/10.35814/coverage.v9i1.1115.

/27/ Gawi G., Aminulloh A., and Yasak E. (2017), "Penerapan Kode Etik Jurnalistik Dalam Surat Kabar Harian Surya Malang," J. Ilmu Sos. dan Ilmu Polit. Univ. Tribhuwana Tunggadewi, vol. 6, no. 1, p. 101770.
/28/ Nazmudin (2019), "Peran Media Lokal Dalam Mendorong Demokrasi," J. Ilm. Niagara, vol. 11, no. 1, pp. 43-54.

/29/ Rumata V. M. (2017), “Objektivitas Berita Pada Media Dalam Jaringan (Analisis Isi Berita Pemilihan Gubernur DKI Jakarta Pada Detiknews Selama Masa Kampanye Periode I), " Indonesian Ministry of Communication and Informatics, Jakarta

/30/ Agustini (2019), “Kompetemso Kesadaran Etika dan Hukum Pada Wartawan Televisi Dalam Menjaga Objektifitas Berita," J. Soial Hum., vol. 10, pp. 131-140, doi: 10.30997/jsh.v10i2.2059.

/31/ Agus S. P. and Zuhri S. (2015), “Objektivitas Pemberitaan PT Merpati Nusantara di Media Online (Analisis Isi Obyektivitas Pemberitaan Tentang Pailit PT Merpati Nusantara di Media Online Tempo.Com)," J. Ilmu Komun., vol. 7, no. 2, p. 85.

/32/ Westerståhl J. (1983), “Objective News Reporting: General Premises," Communic. Res., vol. 10, no. 3, p. 405

/33/ Bahrun A. C. (2019), “Analisis Isi Berita Politik Pilkada Gowa 2015 Pada Rubrik Citizen Reporter Portal Berita Online www.gosulsel.com," Kareba J. Ilmu Komun., vol. 8 , no. 1 , pp. $169-187$.

134/ Poentarie E. (2015), “The Comparison of Truth, Relevance, Balance and Netrality in News Reporting (Content Analysis On Presidential Election News-Reporting 2014," J. Stud. Komun. dan Media, vol. 19, no. 1, pp. 1-13.

/35/ Eriyanto (2015), Analisis Isi, Jakarta. PRENADAMEDIA GROUP

/36/ Bungin B. (2017), Metode Penelitian Kuantitatif Komunikasi, Ekonomi, Kebijakan Publik Serta IlmuIlmu Sosial Lainnya, 2nd ed. Jakarta: PT Fajar Interpratama Mandiri, 2017. 